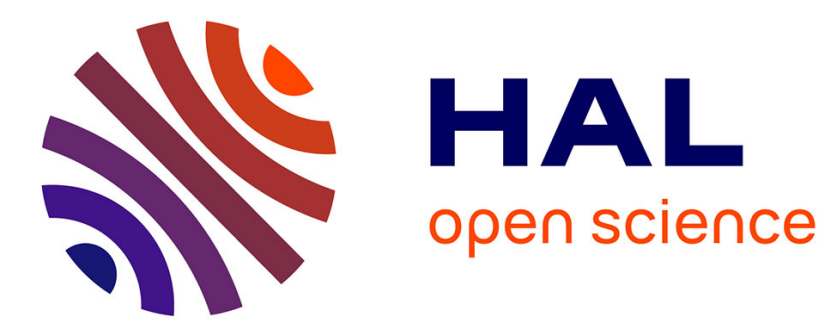

\title{
High-pressure elasticity of serpentine and seismic properties of the hydrated mantle wedge
}

L. Bezacier, Bruno Reynard, H. Cardon, G. Montagnac, J. Bass

\section{To cite this version:}

L. Bezacier, Bruno Reynard, H. Cardon, G. Montagnac, J. Bass. High-pressure elasticity of serpentine and seismic properties of the hydrated mantle wedge. Journal of Geophysical Research: Solid Earth, 2013, 118 (2), pp.527-535. 10.1002/jgrb.50076 . hal-02107513

\section{HAL Id: hal-02107513 \\ https://hal.science/hal-02107513}

Submitted on 21 May 2021

HAL is a multi-disciplinary open access archive for the deposit and dissemination of scientific research documents, whether they are published or not. The documents may come from teaching and research institutions in France or abroad, or from public or private research centers.
L'archive ouverte pluridisciplinaire HAL, est destinée au dépôt et à la diffusion de documents scientifiques de niveau recherche, publiés ou non, émanant des établissements d'enseignement et de recherche français ou étrangers, des laboratoires publics ou privés. 


\title{
Mechanism and kinetics of the $\alpha-\beta$ transition in San Carlos olivine $\mathrm{Mg}_{1.8} \mathrm{Fe}_{0.2} \mathrm{SiO}_{4}$
}

\author{
J. P. Perrillat, ${ }^{1}$ I. Daniel, ${ }^{1}$ N. Bolfan-Casanova, ${ }^{2}$ M. Chollet, ${ }^{1}$ G. Morard ${ }^{3}$ and M. Mezouar ${ }^{4}$ \\ Received 5 September 2012; revised 11 December 2012; accepted 20 December 2012; published 31 January 2013.
}

[1] The mechanism and kinetics of the $\alpha-\beta$ transformation in San Carlos olivine $\alpha$ $\mathrm{Mg}_{1.8} \mathrm{Fe}_{0.2} \mathrm{SiO}_{4}$ containing ca. 526 wt.ppm $\mathrm{H}_{2} \mathrm{O}$ were studied in situ by time-resolved synchrotron X-ray diffraction (XRD) in the range $12.5-14.5 \mathrm{GPa}$ and $870-1150 \mathrm{~K}$. Time series of XRD spectra reveal the early formation of an intermediate phase that further transforms to wadsleyite ( $\beta$-phase). This intermediate phase may be either a metastable ringwoodite $(\gamma$-phase) or the disordered spinelloid phase proposed in the pseudomartensitic reaction model. Both microstructural and kinetic data suggest that the transformation rates are controlled by growth processes after the early saturation of nucleation sites along olivine grain boundaries. Growth rates in the range $1.7 \times 10^{-12}-2.1 \times 10^{-9} \mathrm{~m} . \mathrm{s}^{-1}$ are estimated by fitting the transformation-time data to the Cahn rate equation and define an activation enthalpy for growth $\Delta H_{a}=204(55) \mathrm{kJ} / \mathrm{mol}$. Compared to the previous studies performed on pure forsterite $\mathrm{Mg}_{2} \mathrm{SiO}_{4}$, these new kinetic results point out an increase of transformation rates with the iron content. Hence, the persistence of a metastable olivine wedge to depths $>660 \mathrm{~km}$ might be restricted to even colder and/or dryer subduction zones than previously estimated.

Citation: Perrillat, J. P., I. Daniel, N. Bolfan-Casanova, M. Chollet, G. Morard, and M. Mezouar (2013), Mechanism and kinetics of the $\alpha-\beta$ transition in San Carlos olivine $\mathrm{Mg}_{1.8} \mathrm{Fe}_{0.2} \mathrm{SiO}_{4}$, J. Geophys. Res. Solid Earth, 118, 110-119, doi:10.1002/jgrb.50061.

\section{Introduction}

[2] Olivine $(\mathrm{Mg}, \mathrm{Fe})_{2} \mathrm{SiO}_{4}(\alpha$-phase) is the major constituent of the Earth's upper mantle. With increasing pressure, it transforms sequentially to wadsleyite ( $\beta$-phase), with a modified spinel structure, then to ringwoodite ( $\gamma$-spinel phase), and finally to perovskite + magnesio-wustite [e.g., Ringwood and Major, 1966; Akimoto and Fujisawa, 1968]. These phase changes have long been associated with the seismic discontinuities observed at 410, 520, and $660 \mathrm{~km}$ depth in the mantle, respectively [e.g., Ringwood, 1975]. In the cold interior of subducting plates, these phase transformations can be kinetically delayed [e.g., Stein and Stein, 1996], and olivine could persist metastably well beyond its equilibrium limit. Such a kinetic hindrance is of significant importance for the buoyancy and ultimate fate of subducting slabs. Because subduction is driven by the thermal structure and density increase related

\footnotetext{
${ }^{1}$ Laboratoire de Géologie de Lyon, UMR5276, Université Claude Bernard Lyon 1 - CNRS - ENS Lyon, Villeurbanne, France.

${ }^{2}$ Laboratoire Magmas et Volcans, UMR6524, Université Blaise Pascal CNRS, Clermont-Ferrand, France.

${ }^{3}$ Institut de Minéralogie et de Physique des Milieux Condensés, UMR 7590, CNRS, Université Pierre et Marie Curie, Paris, France.

${ }^{4}$ European Synchrotron Radiation Facility, BP220, Grenoble, France.

Corresponding author: J. P. Perrillat, Laboratoire de Géologie de Lyon, UMR5276, Université Claude Bernard Lyon 1 - CNRS - ENS Lyon, 69622 Villeurbanne, France. (jean-philippe.perrillat@univ-lyon1.fr)

(C) 2013. American Geophysical Union. All Rights Reserved. 2169-9356/13/jgrb.50061
}

to phase transformations, the existence of a metastable wedge of olivine would profoundly influence the plate velocity, and ultimately the dynamics and morphology of slabs [e.g., Bina et al., 2001]. The mechanical properties of lithospheric materials would also be altered, as the stress state and the strength of slabs are strongly dependent on mineralogy and grain sizes [e.g., Karato et al., 2001]. Finally, shear instabilities postulated to occur during the transformation of metastable olivine to its high pressure polymorphs have been proposed for the origin of deep focus earthquakes [Kirby, 1987; Green and Burnley, 1989], as well as "outboard" earthquakes that occur away from Wadatti-Benioff zones [Chen and Brudzinski, 2001].

[3] Direct seismic detections of a metastable olivine wedge are so far scarce. Examples of such observations include the Japan [Kawakatsu and Yoshioka, 2011] and the Mariana subduction regions [Kaneshima et al., 2007]. An alternative approach is to build thermo-kinetic models relying on accurate experimental data on the mechanism and kinetics of the $\alpha-\beta-\gamma$ transitions. The extensive work conducted on the transformation mechanism led however to conflicting results. A martensitic transition was proposed theoretically by Poirier [1981] based on the coherent shear of the olivine oxygen sublattice accompanied by "synchroshear" of the cations. The topotaxial relationship between the olivine and spinel phases $(\mathrm{Mg}, \mathrm{Fe})_{2} \mathrm{SiO}_{4}$ observed in either experiments [Lacam et al., 1980; Madon et al., 1989; Green and Burnley, 1989] or shocked meteorites [Price et al., 1982] support this shear-induced mechanism that would be favored by high differential stress and/or a large overstepping 
of the equilibrium conditions. In contrast, numerous experimental studies have documented microstructural evidences for a reconstructive transition involving grain-boundary or intracrystalline nucleation followed by interface-controlled growth [Sung and Burns, 1976; Brearley et al., 1992; Kerschhofer et al., 1996; Kubo et al., 1998, Mosenfelder et al., 2001]. This mechanism is thought to be effective under near-equilibrium and high-temperature conditions. Finally, an intermediate model is the pseudomartensitic mechanism that involves two stages: a shear-induced anionic re-arrangement followed by short-range diffusion of cations. This mechanism was first proposed by Furnish and Basset [1983] who observed during in situ X-ray diffraction (XRD) experiments that the coherent restacking of oxygen atoms appreciably precedes cations reordering during the $\alpha-\gamma$ transition in $\mathrm{Fe}_{2} \mathrm{SiO}_{4}$. It is consistent with the transmission electron microscopy (TEM) observations of a disordered spinelloïd phase that subsequently orders to produce the $\beta$-phase in $\mathrm{Mg}_{2} \mathrm{SiO}_{4}$ quench products [Guyot et al., 1991; Brearley et al., 1992]. From the above literature data, it appears that the transformation mechanism might change with pressure, temperature, and stress conditions. However, the data are not yet comprehensive to infer the mechanism that operates under subduction environments.

[4] Early experimental kinetic studies have been carried out at low pressure on analogue materials $\mathrm{Mg}_{2} \mathrm{GeO}_{4}, \mathrm{Ni}_{2} \mathrm{SiO}_{4}$, and $\mathrm{Co}_{2} \mathrm{SiO}_{4}$ (see Rubie and Ross [1994] for a review). However, the application to mantle olivine requires the extrapolation of kinetic parameters assuming that composition and absolute pressure do not affect transformation rates. More recently, kinetics data have been obtained on the $\alpha-\beta$ and $\alpha-\gamma$ transformations in synthetic $\mathrm{Mg}_{2} \mathrm{SiO}_{4}$ and natural $\mathrm{Mg}_{1.8} \mathrm{Fe}_{0.2} \mathrm{SiO}_{4}$ compositions and conditions relevant to the upper mantle [Kubo et al., 1998, 2004a; Liu et al., 1998; Kerschhofer et al., 2000; Mosenfelder et al., 2001; Hosoya et al., 2005; Diedrich et al., 2009]. Most of these studies relied on quenched experiments performed in multi-anvil devices, aside from Kubo et al. [2004a] and Hosoya et al. [2005] who studied the transition in situ by XRD. These works concluded that overall transformation rates are controlled by growth kinetics rather than nucleation processes and suggested that the persistence of olivine to a depth of $\sim 600-700 \mathrm{~km}$ is restricted to the cold interior of rapidly subducting slabs. However, they also pointed out the effect of transformation stress [Liu et al., 1998; Mosenfelder et al., 2001] and water [Hosoya et al., 2005; Diedrich et al., 2009] that could profoundly affect the extent of olivine metastability. This last point could be exceedingly important in hydrous subducted slabs as both olivine and its high-pressure polymorphs can contain significant $\mathrm{H}_{2} \mathrm{O}$ in the form of hydroxyl point defects [e.g., Bolfan-Casanova et al., 2000].

[5] In this paper, we provide new kinetic data on the olivinewadsleyite transition in a San Carlos mantle composition acquired by the in situ XRD method. The experiments were performed at relatively low-temperature conditions $(870-1150 \mathrm{~K})$ and small pressure oversteps of the transition boundary in order to reproduce the transformation in subduction zone environments. Time series of XRD spectra reveal the early formation of an intermediate metastable phase that further transforms to wadsleyite. Kinetic parameters derived from the experimental transformation-time data are compared with literature data and highlight an increase of transformation rates with the iron content. We discuss the implications of these new kinetic results on the metastability of olivine in subducting slabs.

\section{Experimental Methods}

[6] The starting material consisted of natural olivine crystals from the San Carlos peridotite (Arizona), ground in an agate mortar down to 2-3 $\mu \mathrm{m}$ in size. The composition of these crystals was $\mathrm{Mg}_{1.8} \mathrm{Fe}_{0.2} \mathrm{SiO}_{4}$ as determined by electron probe measurements. The water content was measured by infrared spectroscopy to $1.8 \pm 0.4$ wt.ppm $\mathrm{H}_{2} \mathrm{O}$ using the calibration coefficient of Libowitzky and Rossman [1997]. Prior to the experiments, powders were dried at $150^{\circ} \mathrm{C}$ in air for few days to avoid absorption of water. Angle-dispersive XRD experiments were carried out in a Paris-Edinburgh large volume press installed at beamline ID27 of European Synchrotron Radiation Facility (Grenoble, France) [Mezouar et al., 2005; Perrillat, 2008]. Sintered diamond anvils [Morard et al., 2007] were used to generate pressures up to $14.5 \mathrm{GPa}$. The sample assembly (Figure 1) was composed of a boron-epoxy pressure medium, a resistive heater, and an $\mathrm{MgO}$ sample capsule. The heater consisted of two $\mathrm{LaCrO}_{3}$ ceramic disks in electrical contact through two rhenium strips $50 \mu \mathrm{m}$ thick, oriented parallel to the X-ray beam. The olivine and a thin layer of $\mathrm{Au}$ powder were packed in the $\mathrm{MgO}$ capsule. The maximal thermal gradient across the sample was estimated from numerical modelling to $\pm 80 \mathrm{~K}$ at $873 \mathrm{~K}$ (Figure 1).

[7] Pressure and temperature conditions were determined from the diffraction lines of $\mathrm{MgO}$ and $\mathrm{Au}$ using the PVT equations of state of Martinez-Garcia et al. [2000] and Shim et al. [2002], respectively. Uncertainty on P and T depends on both the error in fitting the diffraction data and the uncertainty on the thermoelastic parameters of the calibrants. It was estimated for each $\mathrm{P}-\mathrm{T}$ conditions from the parallelogram area delineated by the intersection between the $\mathrm{Au}$ and $\mathrm{MgO}$ isochors (Figure 2). Taking into account a \pm $0.002 \AA$ error on the distance of the $\mathrm{Au}$ and $\mathrm{MgO}$ diffraction lines, the precision on $\mathrm{P}$ and $\mathrm{T}$ was in all cases better than \pm $0.4 \mathrm{GPa}$ and $\pm 80 \mathrm{~K}$.

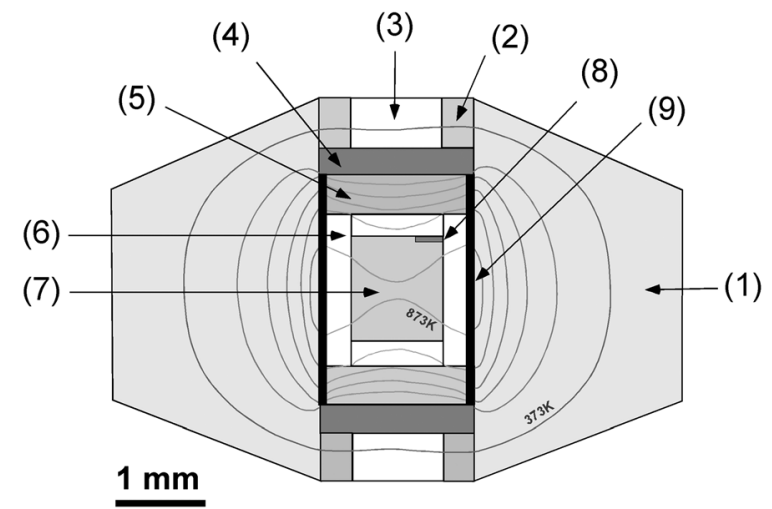

Figure 1. Details of the cell assembly and temperature profile at $873 \mathrm{~K}$ calculated using the program "CellAssembly" [Hernlund et al., 2006]. The interval between isotherms is $100 \mathrm{~K}$. (1) boron-epoxy gasket, (2) steel ring, (3) $\mathrm{MgO}$ ceramic, (4) molybdenum disk, (5) $\mathrm{LaCrO}_{3}$ ceramic, (6) $\mathrm{MgO}$ capsule, (7) sample, (8) gold foil, (9) rhenium heater. 


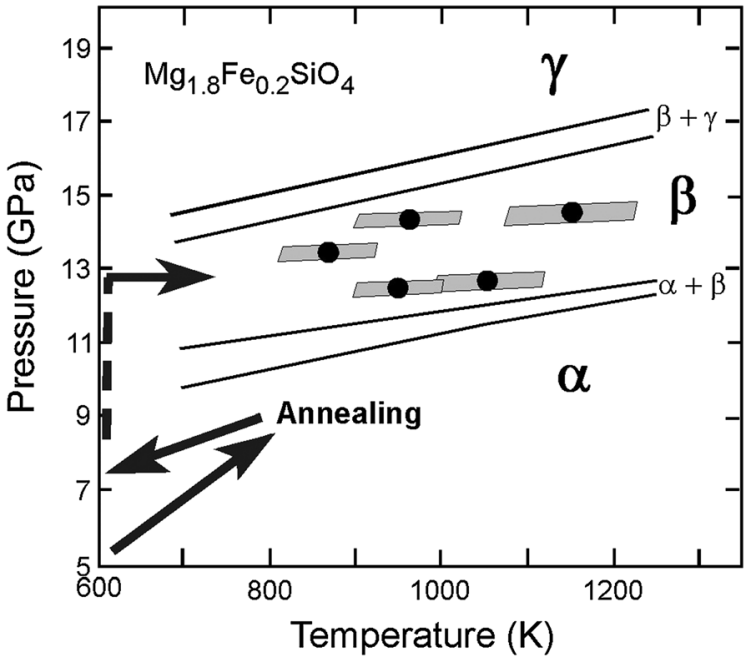

Figure 2. Pressure-temperature diagram showing the experimental conditions with relations between olivine $(\alpha)$, wadsleyite $(\beta)$, and spinel $(\gamma)$ phases (after Akaogi et al. [1989] and Katsura et al. [2004]). P and T were determined from the diffraction lines of $\mathrm{Au}$ and $\mathrm{MgO}$ using a cross-calibration of their PVT equation of state; uncertainties are displayed as gray-shaded area.

[8] Samples were first compressed at room temperature to about $9 \mathrm{GPa}$ and then annealed at $1100 \mathrm{~K}$ for $2-3 \mathrm{~h}$ within the stability field of the $\alpha$-phase. The goal of this annealing is to relax the strain and reduce the density of defects resulting from the cold compression stage. The sharpening of diffraction lines on the XRD images testifies to these recrystallization processes. The achievement of equilibrium microtexture is clearly visible on the scanning electron microscopy (SEM) picture of a sample quenched after annealing (Figure 3a). It exhibits sharp olivine grain boundaries and $120^{\circ}$ triple junctions. Following the annealing stage, temperature was reduced to ambient, and pressure was increased to the stability field of the $\beta$-phase. Then, temperature was increased again at a heating rate of $50 \mathrm{~K} / \mathrm{min}$ up to the target value. To avoid a decrease in pressure related to the volume reduction of the reaction, a constant load was applied on the sample thanks to an automatic oil pressure drive system (Sanchez Technologies ${ }^{\circledR}$ ). To monitor the extent of transformation as a function of time, a sequence of XRD spectra was acquired every $30 \mathrm{~s}$ to $4 \mathrm{~min}$, with a collection time of 15 to $60 \mathrm{~s}$. The incident monochromatic X-ray beam $\lambda=0.6199 \AA$ (Mo absorption K-edge) was reduced down to $50 \times 50 \mu^{2}$ by two sets of carbide slits placed before the Paris-Edinburgh press. The diffracted Xrays from the sample were collimated through Soller'slits [Mezouar et al., 2002] and collected on a MAR ${ }^{\circledR} 345$ image plate over a $2 \theta$ interval from $4^{\circ}$ to $18^{\circ}$. The two-dimensional XRD images were integrated after spatial distortion corrections using Fit2D [Hammersley et al., 1996]. Finally, transformation-time plots $\zeta(t)$ were constructed by Rietveld refinement of phase proportions using the GSAS package [Larson and von Dreele, 1994]. After completion of the reaction, i.e., disappearance of the diffraction lines of the $\alpha$-phase, the samples were quenched to room temperature by switching off the power of the heater and then slowly decompressed. The recovered samples were cut and mounted on epoxy resin and polished for microscopic observations of texture and grain sizes. SEM images were acquired on a JEOL 840 microscope at the MATEIS laboratory (Lyon, France).

[9] Considering the potentially strong catalytic effects of even small amounts of $\mathrm{H}_{2} \mathrm{O}$ in the sample charges, the water concentrations were determined using Fourier transform infrared spectroscopy (FTIR) measurements. For this purpose, recovered samples were ground and doubly polished to $\sim 130$ $\mu \mathrm{m}$ thin sections. The samples thickness was determined with a precision of approximately $2 \mu \mathrm{m}$ with a Mitutoyo electronic micrometer. Unpolarized infrared spectra were obtained in air using a Vertex70 Bruker spectrometer coupled to a Hyperion microscope equipped with $\times 15$ objective and condenser (at Laboratoire Magmas et Volcans, Clermont-Ferrand - France, and Institut de Planétologie et Astrophysique, Grenoble France). Beam size ranged between 30 and $100 \mu \mathrm{m}$. The spectra were measured through a $\mathrm{CaF}_{2}$ plate with a resolution of $2 \mathrm{~cm}^{-1}$ and with up to 4000 scans between 2500 and $4000 \mathrm{~cm}^{-1}$ in the $\mathrm{O}-\mathrm{H}$ stretching region.
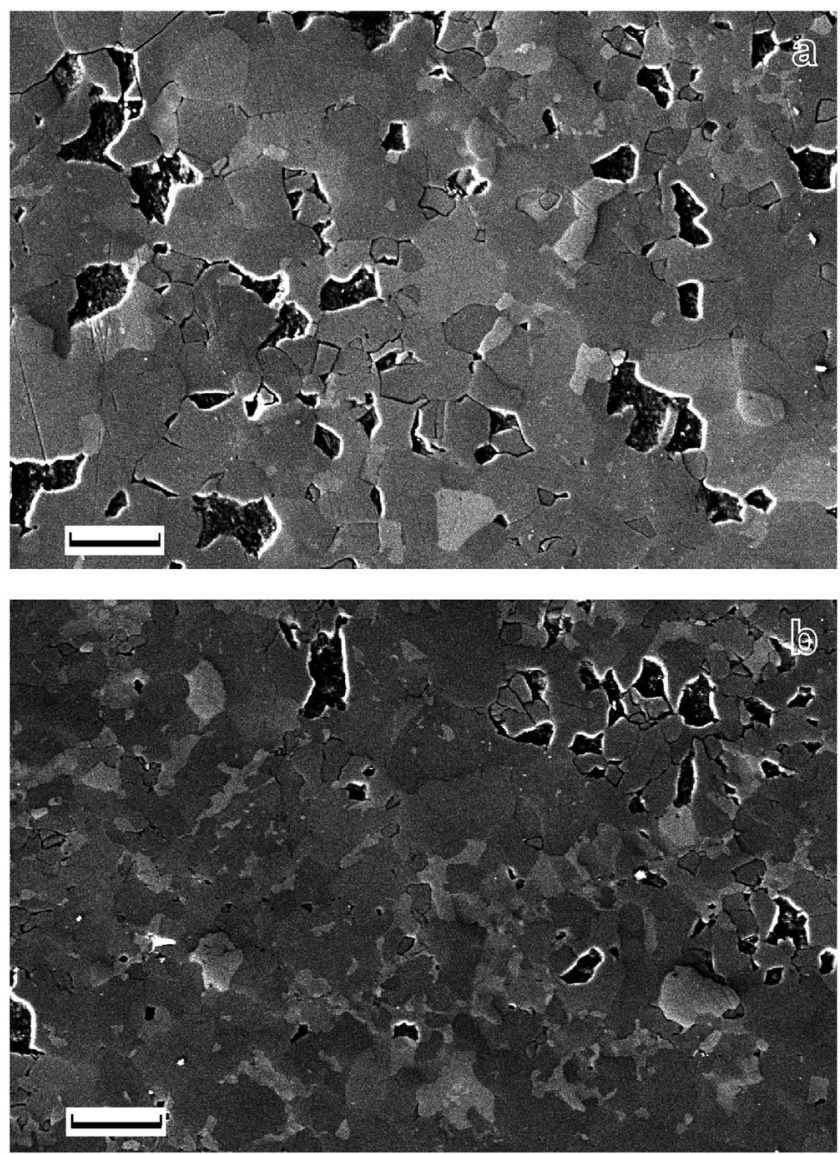

Figure 3. Electron backscattered images showing the characteristic microtextures of samples (a) after the annealing stage at 9.6 GPa, $1100 \mathrm{~K}$ during $3 \mathrm{~h}$ and (b) after the complete transformation to the $\beta$-phase after $6 \mathrm{~h}$ at $14.5 \mathrm{GPa}, 980 \mathrm{~K}$. For a better display, the gray scale has been stretched, and thereby contrasts reflect crystal orientation. The scale bar is 4 microns. The annealed sample shows a relatively homogeneous grain size of $2.5 \pm 1.1 \mu \mathrm{m}$, well-developed triple junctions, and straight grain boundaries, whereas after reaction, it exhibits scalloped grain boundaries and a smaller grain size of $1.4 \pm$ $0.6 \mu \mathrm{m}$. 


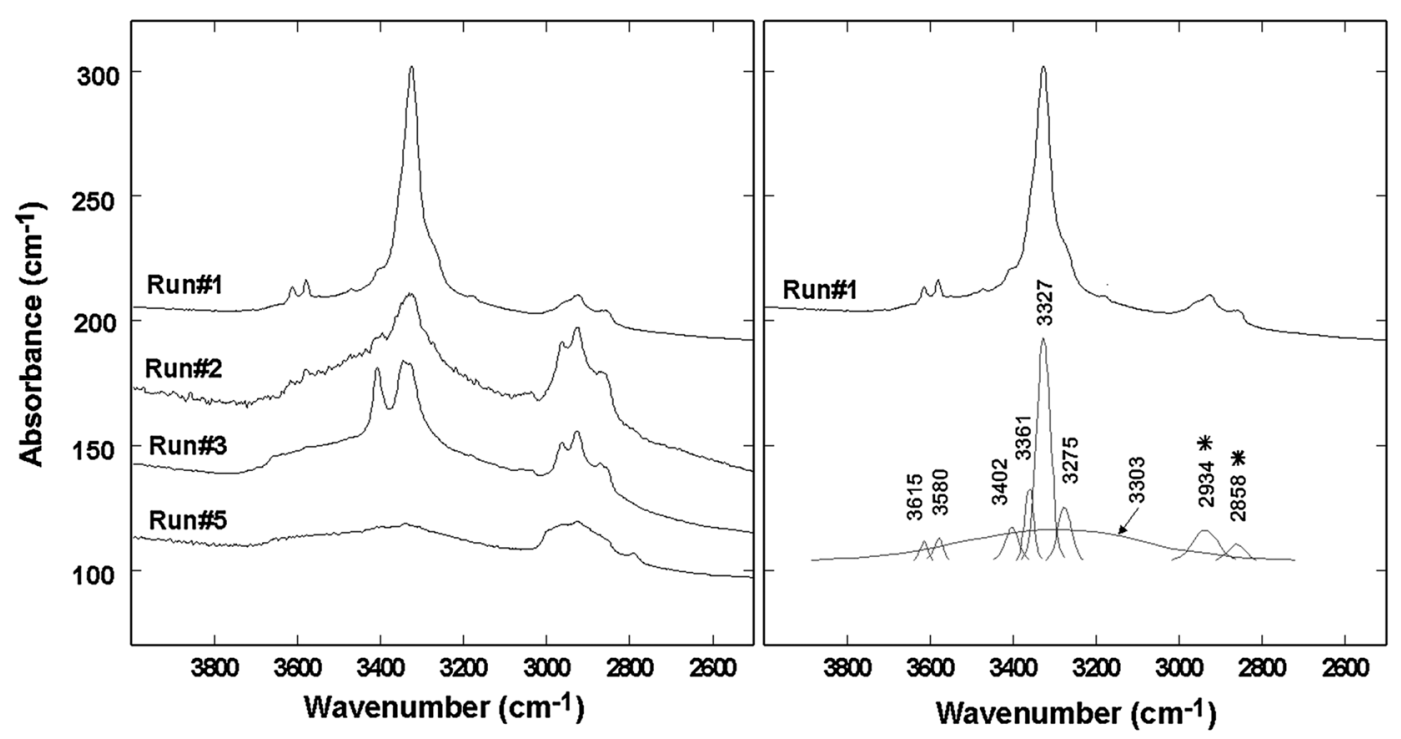

Figure 4. Unpolarized IR spectra of recovered samples in the region of the $\mathrm{OH}$ stretching modes. Representative absorption bands are labeled by their wavenumber obtained by peak fitting. See section 2 for the assignment of IR peaks and quantification of hydroxyl groups. Peaks from the epoxy glue and acetone treatment are marked with asterisks.

[10] All FTIR spectra (Figure 4) exhibit a broad absorption band in the range 3000 to $4000 \mathrm{~cm}^{-1}$, attributable to molecular $\mathrm{H}_{2} \mathrm{O}$, which likely reflects the presence of water at grain boundaries. A group of four sharp absorption peaks near $3300 \mathrm{~cm}^{-1}$ (i.e., $3275,3326,3360$, and $3402 \mathrm{~cm}^{-1}$ ) and a second group of two smaller peaks near $3600 \mathrm{~cm}^{-1}$ (i.e., 3580 and $3615 \mathrm{~cm}^{-1}$ ) are characteristic of the structural hydroxyls in wadsleyite as reported by Kohlstedt et al. [1996] and Kohn et al. [2002]. Finally, absorption bands near $2900 \mathrm{~cm}^{-1}$, which are characteristic of C-H bending, eventually derive from the epoxy glue and acetone treatment and therefore were not considered for the determination of $\mathrm{OH}$ contents.

[11] The hydroxyl contents were calculated from the integrated area of both sharp and broad absorption bands after background baseline correction and thickness normalization to $1 \mathrm{~cm}$. The molar absorption coefficient $\varepsilon_{\mathrm{i}}=73,000 \mathrm{~L}$. $\mathrm{mol}^{-1} . \mathrm{cm}^{-2}$ [Deon et al., 2010] was used for the quantification of wadsleyite IR peaks, while the general calibration of Libowitzky and Rossman [1997] was used for the broad band. The $\mathrm{OH}$ content in each sample (Table 1) varies from
347 to 596 wt.ppm $\mathrm{H}_{2} \mathrm{O}$ with an average value of $526 \pm 119$ wt.ppm $\mathrm{H}_{2} \mathrm{O}$. Though still low, the amount of water in wadsleyite is significantly higher than in the original olivine. It probably arises from water adsorbed in the cell assembly parts and powdered sample, and/or from the boron-epoxy medium.

\section{Results}

\subsection{Mechanism of the Olivine-Wadsleyite Transition in $\mathrm{Mg}_{1.8} \mathrm{Fe}_{0.2} \mathrm{SiO}_{4}$}

[12] Time-resolved XRD data were acquired in five runs over the $12.5-14.5 \mathrm{GPa}$ and $870-1150 \mathrm{~K} \mathrm{P}-\mathrm{T}$ range (Figure 2 and Table 1). A typical sequence of diffraction patterns is shown in Figure 5. At the beginning of the transition, the decrease in intensity of olivine diffraction peaks is accompanied by the early appearance of a metastable intermediate phase whose diffraction lines are successfully indexed with the (220) (311) (400) (511) and (440) reflections of Fd3m spinel. This phase transforms progressively into wadsleyite, Imma space group, and at the end of the reaction, only the diffraction

Table 1. Experimental Conditions, Water Contents, and Estimated Values of Grain-Boundary Nucleation and Growth Rates

\begin{tabular}{|c|c|c|c|c|c|c|c|c|}
\hline & $\mathbf{V}_{\mathrm{Au}}(\AA)$ & $\mathbf{V}_{\text {Mgo }}(\AA)$ & $\begin{array}{l}\text { Pressure } \\
\text { (GPa) }\end{array}$ & Temperature (K) & $\begin{array}{c}\text { Free Energy Change } \\
\qquad \Delta G_{\mathbf{r}}(J / \mathrm{mol})\end{array}$ & $\begin{array}{l}\text { Water Content } \\
\text { (wt ppm } \mathrm{H}_{2} \mathrm{O} \text { ) }\end{array}$ & $\begin{array}{c}\text { Nucleation } \\
\text { Rate }\left(\mathbf{m}^{-2} / \mathbf{s}\right)\end{array}$ & $\begin{array}{c}\text { Growth } \\
\text { Rate }(\mathrm{m} / \mathrm{s})\end{array}$ \\
\hline Run \#1 & 64.55 & 69.94 & 14.5 & 980 & -7017 & $571(111)$ & - & $1.9(0.2) \times 10^{-11}$ \\
\hline Run \#2 & 65.07 & 70.59 & 12.5 & 950 & -2093 & $590(29)$ & $4.83(0.5) \times 10^{13}$ & $6.9(0.6) \times 10^{-12}$ \\
\hline Run \#3 & 64.68 & 70.22 & 13.2 & 870 & -4401 & $596(105)$ & - & $1.7(0.8) \times 10^{-12}$ \\
\hline Run \#4 & 65.24 & 70.62 & 12.8 & 1050 & -2361 & - & - & $1.2(0.4) \times 10^{-10}$ \\
\hline Run \#5 & 64.97 & 70.12 & 14.5 & 1150 & -6983 & 347 (106) & - & $2.1(0.3) \times 10^{-09}$ \\
\hline
\end{tabular}

-Pressure and temperature conditions were determined from the diffraction lines of MgO and Au using the PVT equations of state of Martinez-Garcia et al. [2000] and Shim et al. [2002], respectively.

-The free energy change $\Delta \mathrm{G}_{\mathrm{r}}$ at P-T is calculated from the thermodynamic data of Akaogi et al. [1989] and Jacobs and de Jong [2005].

-The FTIR measurements of $\mathrm{OH}$ contents were repeated at five to nine locations in each sample. The uncertainty in the water concentration is one standard deviation. Sample Run\#4was lost in the grinding process.

Nucleation and growth rates were obtained by a fit of the experimental $\xi(t)$ data to Cahn's equation (1). Estimated uncertainties are listed in parentheses. When a solution for $N$ was not achieved, an arbitrary value of $N=10^{14} \mathrm{~m}^{-2} / \mathrm{s}$ was set. 

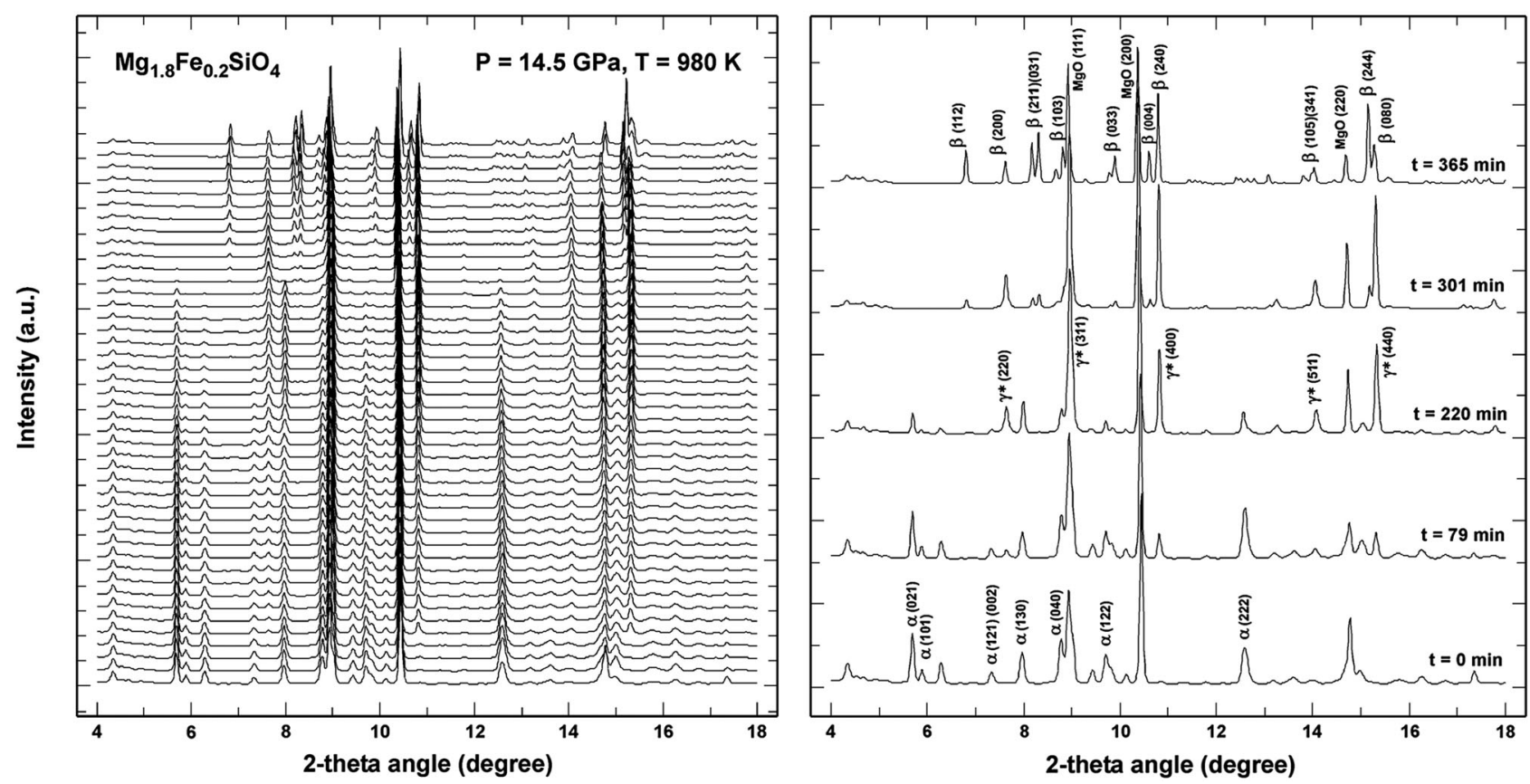

Figure 5. (a) Time series of XRD spectra acquired at $14.5 \mathrm{GPa}-980 \mathrm{~K}$ during the $\alpha-\beta$ transformation and (b) selected patterns at $0,79,220,301$, and $365 \mathrm{~min}$. ( $h \mathrm{kl}$ ) diffraction lines are labeled as $\mathrm{MgO}$ : magnesium oxide, $\alpha$ : olivine, $\beta$ : wadsleyite, $\gamma^{*}$ : intermediate phase.

lines of the $\beta$-phase and $\mathrm{MgO}$ capsule are present. This succession of phases was observed in all experiments, independently of the overpressure relative to equilibrium.

[13] The origin of this metastable phase may be twofold. On one hand, it may correspond to ringwoodite that nucleated and grew metastably according to the Ostwald rule. This could have occurred if the free energy sequence is $\mathrm{G}_{\alpha}$ $>\mathrm{G}_{\gamma}>\mathrm{G}_{\beta}$, so that ringwoodite is stable relative to olivine. On the other hand, this phase may be the intermediate spinelloid phase involved in the pseudomartensitic reaction mechanism [Chen et al., 2001]. In the latter model, the restacking of the anions transforms the hcp oxygen arrangement of olivine into the fcc oxygen sublattice of spinel and modified spinel. It results in a spinelloid phase with a disordered cation structure that further rearranges by short-range diffusion in a second step, to produce the $\beta$-phase. A detailed description of this intermediate phase can be found in Guyot et al. [1991]. Because of the random position of the cations, the spinelloid phase should exhibit more intense diffraction lines for the oxygen array than for the cations one [Furnish and Basset, 1983; Chen et al., 2001]. Unfortunately, this feature cannot be detected on the present XRD patterns, because of peak overlaps in the experimental phase mixture, i.e., the most intense (311) line of spinel is superimposed with the strong $\alpha$-phase (112) and MgO (111) peaks. However, the intermediate spinelloid phase has been clearly identified in the $\alpha-\gamma$ transition. Furnish and Basset [1983] in $\mathrm{Fe}_{2} \mathrm{SiO}_{4}$ reported the initial preferential growth of the only $\gamma$ phase peaks compatible with the oxygen sublattice, namely the (400) and (440) diffraction lines. Lauterjung and Will [1986] observed that at the beginning of the $\alpha-\gamma$ transition, in the $\mathrm{Mg}_{2} \mathrm{GeO}_{4}$ analogue, only diffraction peaks from a spinel-type oxygen array were present. Moreover, Chen et al. [2001] performed structure refinements of XRD spectra during the $\alpha-\gamma$ transition in fayalite and concluded to a delay in the reordering of cations relative to anions during the phase transformation. We therefore believe, though there is no direct evidence in the present XRD pattern, that the observed intermediate phase can be regarded as a disordered spinelloid and that the pseudomartensitic mechanism operates throughout the $\mathrm{Mg}_{2} \mathrm{SiO}_{4}-\mathrm{Fe}_{2} \mathrm{SiO}_{4}$ binary.

[14] The pseudomartensitic mechanism is also consistent with many textural features observed in quenched experimental products and shocked meteorites. Guyot et al. [1991] studied by TEM partially transformed $\mathrm{Mg}_{2} \mathrm{SiO}_{4}$ samples and evidenced a structurally disordered spinelloid phase as an intermediate of the $\alpha-\beta$ reaction. The lamellar intergrowths of $\beta$ and $\gamma$ phases commonly observed in $\mathrm{Mg}_{2} \mathrm{SiO}_{4}$ [Brearley et al., 1992], in analogue compounds [Burnley et al., 1995], and in shocked meteorites [Price et al., 1982; Madon and Poirier, 1983] might also be interpreted as a result of the incomplete transformation of the metastable spinelloid into the $\beta$-phase.

[15] The pseudomartensitic transition has often been considered as favored under high-stress conditions [e.g., Burnley et al., 1995]. In the present experiment, however, PT conditions were close to equilibrium, and the amount of differential stress, estimated from the method of Singh and Kennedy [1974] on $\mathrm{MgO}$ diffraction lines, was not detectable above $600 \mathrm{~K}$, i.e., $\sigma<0.05 \mathrm{GPa}$. This is in agreement with the conclusions by Raterron et al. [2002] that the pseudomartensitic transition operates also under quasi-hydrostatic conditions and is driven by the local stress generated by the volume reduction of the reaction.

[16] Microstructural SEM observations of the transformed samples (Figure 3b) give insights into the geometry of the nucleation and growth processes. In contrast to the texture of olivine after the annealing stage, the reacted samples show irregularly shaped and scalloped grain boundaries. The mean grain size decreased from 2.5(1.1) down to 1.4 
(0.6) microns after the transition, providing evidence for a high nucleation rate relative to growth. No significant variation in grain size was observed among samples transformed at different PT conditions. Lamellar structures within grains are not observed. This suggests that the intermediate phase nucleates at olivine grain boundaries and triple junctions, and subsequently coarsens by phase-boundary migration. This conclusion is in good agreement with the interfacecontrolled nucleation and growth mechanism reported in many previous studies [e.g., Brearley et al., 1992, Kubo et al., 2004a; Mosenfelder et al., 2001].

\subsection{Transformation Kinetics}

[17] The extent of transformation as a function of time $\zeta(t)$ was determined from the isothermal-isobaric sequence of XRD spectra by Rietveld refinement of phase proportions. The transformation-time plots presented in Figure 6 show the advance of reaction estimated from the decrease of the relative amount of olivine from $\zeta=0$ at the beginning of reaction to $\zeta=1$ after complete transformation into wadsleyite. The kinetic data were analyzed using the general rate equation describing the transformation by the grain-boundary nucleation and growth mechanisms [Cahn, 1956]:

$$
\xi(t)=1-\exp \left[-2 S \int_{0}^{y^{\prime}}\{1-\exp (-z) d y\}\right]
$$

where

$$
z=\pi \int_{0}^{t-t^{\prime}} N\left[G^{2}(t-\tau)^{2}-y^{2}\right] d \tau
$$

and $N$ is the nucleation rate, $G$ the growth rate of the product phase, $y^{\prime}=G \mathrm{t}$ is the growth distance after time $t, \tau$ is the time at which a nucleus form, and $t^{\prime}$ is the time necessary for a nucleus to grow to radius $y . S$ is the grain boundary area that was approximated by $S=3.35 /$ d, with $d$ the mean grain size estimated by SEM on quenched samples. A fit of the experimental $\xi(t)$ data to equation (1) provided a direct estimation of growth rates (Figure 6 and Table 1). In most runs, the solution for $N$ did not converge because of extremely rapid nucleation, and only one high value of $N=4.83 \times 10^{13} \mathrm{~m}^{-2} \cdot \mathrm{s}^{-1}$ could be obtained, for run\#2. The fast increase in $\zeta$ at the onset of reaction is actually consistent with such a high nucleation rate, as well as with microstructural data that revealed that the overall transformation rates were dominated by interface-controlled growth processes after the early saturation of nucleation sites. In all runs, the reaction went to completion, i.e., $\zeta>0.9$ (excepted for run\#2 that was stopped at $\zeta=0.7$ ), and the fit to $\zeta(t)$ data does not deviate significantly from the Cahn's relation. This is an evidence for steady-state growth rates during the transformation and for the absence of grain impingement or transformation stress [Liu et al., 1998] that could potentially decrease the growth rates at the late stages of the reaction. It is in agreement with the conclusion of Liu et al. [1998] that transformation stress is minor when the reactant olivine is fine grained.

[18] The integration of the present kinetic data within a thermo-kinetic model requires the extrapolation of measured growth rates at any $\mathrm{P}-\mathrm{T}$ conditions, assuming the transformation mechanism does not change. An expression of the growth rate for the product phase in an interface-controlled transformation has been proposed by Turnbull [1956]:

$$
G=k_{0} T \exp \left(-\frac{\Delta H_{a}+P V^{*}}{R T}\right) \cdot\left[1-\exp \left(-\frac{\Delta G_{r}}{R T}\right)\right]
$$

where $k_{0}$ is a constant, $T$ is temperature, $\Delta H_{a}$ is the activation enthalpy for growth, $P$ is pressure, $V^{*}$ is the activation volume for growth, $R$ is the gas constant, and $\Delta G_{r}$ the free energy change of reaction at given $\mathrm{P}-\mathrm{T}$. Considering the limited pressure range investigated in the present study, the activation volume is not refined and is assumed to be zero. This assumption is justified by the low activation volume $\mathrm{V}^{*}=1.7(4.5) \mathrm{cm}^{3} / \mathrm{mol}$ determined by Kubo et al. [2004a] for the $\alpha-\beta$ transition in $\mathrm{Mg}_{2} \mathrm{SiO}_{4}$ and $\mathrm{V}^{*}=0(2) \mathrm{cm}^{3} / \mathrm{mol}$ estimated for the reconstructive growth of $\gamma-\mathrm{Mg}_{2} \mathrm{GeO}_{4}$ [Burnley, 1995]. The $\Delta G_{r}$ values are calculated from the thermodynamic data of Akaogi et al. [1989] and Jacobs and de Jong [2005] (Table 1). Values of $k_{0}$ and $\Delta H_{a}$ are estimated from the slope and intercept of a least squares linear fit to the growth rate data on an Arrhenius plot $\ln \{G / T[1$-exp $\left.\left.\left(-\Delta G_{r} / R T\right)\right]\right\}$ vs $1000 / T$ (Figure 7$)$. The best fit yields values for $\ln k_{0}=-5.2(8.1) \mathrm{m} / \mathrm{s} / \mathrm{K}$ and $\Delta H_{a}=204(55) \mathrm{kJ} / \mathrm{mol}$, where uncertainties reported in parentheses are estimated from the propagation of the error on $\mathrm{P}-\mathrm{T}$ conditions.

\section{Discussion}

\subsection{Effect of the Iron and Water Contents on Kinetics}

[19] The present kinetic results are compared to the parameters obtained by Kubo et al. [2004a] for the $\alpha-\beta$ transition in $\mathrm{Mg}_{2} \mathrm{SiO}_{4}$ synthetic samples. The latter experiments were conducted under nominally anhydrous conditions though low amounts of hydroxyl $<750 \pm 100$ wt.ppm $\mathrm{H}_{2} \mathrm{O}$ may have contaminated the sample like in the present study. Kubo et al. [2004a] starting material was fined grained, and experiments were performed at small pressure oversteps relative to the $\alpha$ $\beta$ equilibrium. Transformation-time data were acquired by in situ XRD and analyzed using the Cahn's rate equation for interface-controlled reaction. These experimental and analytical methods are almost identical to the present study; in particular, the water contents are close. However, Kubo et al. [2004a] reported growth rates more than one order of magnitude slower than in the present study. For example our predicted growth rate at $13.7 \mathrm{GPa}-1273 \mathrm{~K}$ using equation (3) and the above kinetic parameters ( $\ln k_{0}=$ $-5.2, \Delta H_{a}=204 \mathrm{~kJ} / \mathrm{mol}$ and $\left.V^{*}=0 \mathrm{~cm}^{3} / \mathrm{mol}\right)$ is $G=5.7 \times$ $10^{-9} \mathrm{~m} . \mathrm{s}^{-1}$, while Kubo et al. [2004a] observed $G=8.5 \times$ $10^{-10} \mathrm{~m} . \mathrm{s}^{-1}$. In addition, the activation enthalpy for growth $\Delta H_{a}=204(55) \mathrm{kJ} / \mathrm{mol}$ is also significantly lower than the 391 (73) $\mathrm{kJ} / \mathrm{mol}$ value (when $V^{*}=0 \mathrm{~cm}^{3} / \mathrm{mol}$ ) in $K u b o$ et al. [2004a] and indicates a lower-temperature dependence of transformations rates. The comparison with the quench experiments is more tricky since the latter are performed at higher-pressure oversteps of the reaction boundary and suffer from a lower constraint in reaction duration. Liu et al. [1998] studied the transformation of $\mathrm{Mg}_{1.8} \mathrm{Fe}_{0.2} \mathrm{SiO}_{4}$ polycrystalline samples and reported some transformation rates, but not all, significantly faster than those measured by Kubo et al. [2004a]. For example, Liu et al. [1998] estimated a growth rate $G=1.4 \times 10^{-9} \mathrm{~ms}^{-1}$ at $1273 \mathrm{~K}-18 \mathrm{GPa}$, while Kubo et al. [2004a] measured $G=8.5 \times 10^{-10} \mathrm{~m} \cdot \mathrm{s}^{-1}$ at 

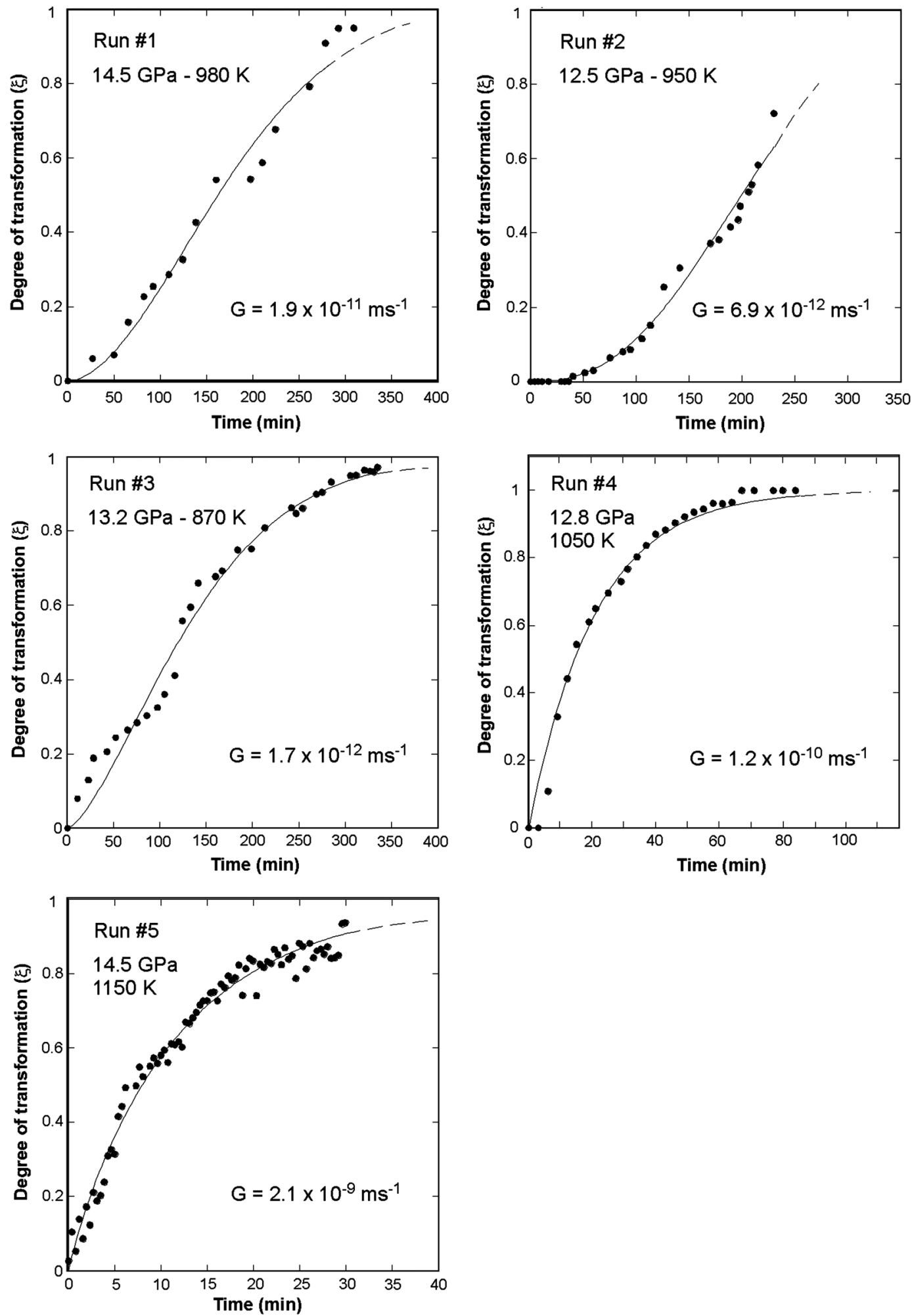

Figure 6. Transformation-time plots at specific temperatures and pressures. The solid curves represent best fits of experimental data to the Cahn rate equation (1) with optimized values of growth rate $(G)$.

similar temperature. The activation enthalpy $\Delta H_{a}=334 \mathrm{~kJ} / \mathrm{mol}$ estimated by Liu et al. [1998] is between the present value $\Delta H_{a}=204 \mathrm{~kJ} / \mathrm{mol}$ and the one of Kubo et al. [2004a] $\Delta H_{a}=391 \mathrm{~kJ} / \mathrm{mol}$. The large errors on kinetic parameters cannot account for the discrepancy. The difference may originate from the different composition of the starting materials, in particular on the iron content of the San Carlos olivine that might enhance the $\alpha-\beta-\gamma$ transition rates.

[20] The pseudomartensitic reaction involves short-range $\mathrm{Fe}-\mathrm{Mg}$ interdiffusion, which is a process controlled by composition [Chakraborty et al., 1999; Kubo et al., 2004b; Holzapfel et al., 2009]. For instance, Kubo et al. [2004b] 


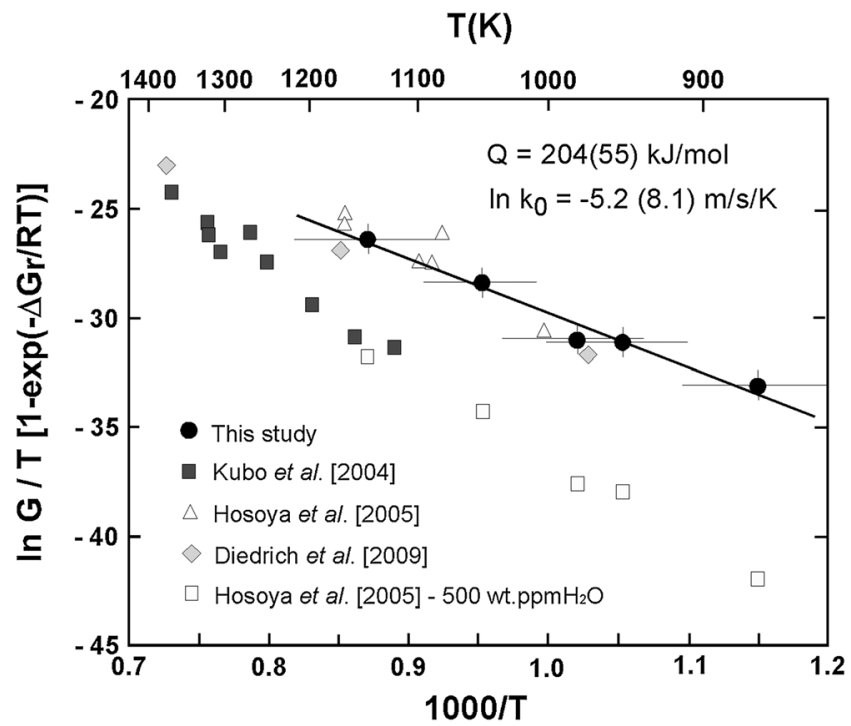

Figure 7. Arrhenius plot showing the temperature dependence of $\alpha$ to $\beta$ growth rates in $\mathrm{Mg}_{1.8} \mathrm{Fe}_{0.2} \mathrm{SiO}_{4} \sim 526 \mathrm{wt}$. ppm $\mathrm{H}_{2} \mathrm{O}$ (full circles, present study). The slope of the linear relation yields the activation energy for growth $\Delta H_{a}=204$ (55) $\mathrm{kJ} / \mathrm{mol}$ and the intercept a value for $\ln k_{0}=-5.2(8.1)$. Kinetic data for synthetic $\mathrm{Mg}_{2} \mathrm{SiO}_{4} \sim 750$ wt.ppm $\mathrm{H}_{2} \mathrm{O}$ (gray square, nine points from Figure 8 in Kubo et al. [2004a]), synthetic $\mathrm{Mg}_{2} \mathrm{SiO}_{4} \sim 2176-5000$ wt.ppm $\mathrm{H}_{2} \mathrm{O}$ (triangles, six points from Table 1 in Hosoya et al., [2005]), and natural San Carlos $\mathrm{Mg}_{1.8} \mathrm{Fe}_{0.2} \mathrm{SiO}_{4} \sim 300$ ppm ${ }^{2} \mathrm{H}_{2} \mathrm{O}$ (diamonds, three points from Figure 10 in Diedrich et al., [2009]) are shown for comparison. Empty squares show the growth rates predicted for a 526 wt.ppm $\mathrm{H}_{2} \mathrm{O}$ bearing $\mathrm{Mg}_{2} \mathrm{SiO}_{4}$ olivine at PT conditions of the present experiments using the kinetic parameters from Hosoya et al. [2005].

showed that the $\mathrm{Mg}-\mathrm{Fe}$ interdiffusion rate in wadsleyite increases by almost one order of magnitude with increasing the iron concentration from $\mathrm{X}_{\mathrm{Mg}}=0.97$ to $\mathrm{X}_{\mathrm{Mg}}=0.90$ and decreasing grain size from 60 to $6 \mu \mathrm{m}$. Similarly, Yamazaki et al. [2005] studied the grain growth kinetics of ringwoodite by the quench method and observed faster growth rates in the iron-bearing samples than in the $\mathrm{Mg}_{2} \mathrm{SiO}_{4}$ end-member. Besides the effect of iron, the influence of water on the $\alpha-\beta-\gamma$ kinetics has been investigated owing to its relevance for olivine metastability in subducting slabs. However, experimental studies lead to conflicting results. Hosoya et al. [2005] investigated the $\alpha-\beta$ kinetics on $750-5000$ wt.ppm $\mathrm{H}_{2} \mathrm{O}$ synthetic $\mathrm{Mg}_{2} \mathrm{SiO}_{4}$ samples and inferred a power-law dependence of growth rate on the water content (Figure 7). In contrast, Diedrich et al. [2009] reported $\alpha-\gamma$ transformation rates on 300 wt.ppm ${ }^{2} \mathrm{H}_{2} \mathrm{O}$ hydrated San Carlos olivines up to four orders of magnitude faster than those predicted by Hosoya et al. [2005], suggesting a stronger catalytic effect at low water content. The present results showing a significant enhancement of kinetics of the $\alpha-\beta$ transition in the ironbearing San Carlos olivine might well reconcile the previous studies and constrain more tightly the role of water on the phase transition. Indeed, Diedrich et al. [2009] determined kinetic parameters $\Delta H_{a}=237 \mathrm{~kJ} / \mathrm{mol}$ and $\ln k_{0}=-2.6$ (with $V^{*}=0 \mathrm{~cm}^{3} / \mathrm{mol}$ ) close to the present kinetic results for
$\mathrm{Mg}_{1.8} \mathrm{Fe}_{0.2} \mathrm{SiO}_{4}$ containing 526 wt.ppm $\mathrm{H}_{2} \mathrm{O}$ (Figure 7). Using these parameters, a growth rate $\mathrm{G}=9.0 \times 10^{-12} \mathrm{~m}$. $\mathrm{s}^{-1}$ is estimated at $14.5 \mathrm{GPa}-980 \mathrm{~K}$ slightly slower than our measured value $\mathrm{G}=1.9 \times 10^{-11} \mathrm{~m} . \mathrm{s}^{-1}$. Thus, it is likely that part of the discrepancy between the results of Hosoya et al. [2005] and Diedrich et al. [2009] could be explained by the role of iron, independently of the transformation type $\alpha$ to $\beta$ or $\alpha$ to $\gamma$-phase.

\subsection{Implications for the Metastability of Olivine in Subducting Slabs}

[21] In this section, the experimentally derived kinetic parameters of the olivine $\alpha-\beta$ transformation are used in a one-dimensional thermo-kinetic model to evaluate the metastable persistence of olivine in a subducting slab. The model assumes a grain-boundary reaction controlled by growth kinetics, as observed in our experiments. It ignores the effects of intracrystalline transformation and transformation stress that may occur in a subducting slab. The extent of transformation is calculated at each time step from the Cahn's relation (1) and the growth rate determined from equation (3) using the kinetic parameters $\ln k_{0}=-5.2$, $\Delta H_{a}=204 \mathrm{~kJ} / \mathrm{mol}, V^{*}=0 \mathrm{~cm}^{3} / \mathrm{mol}$, and the thermodynamic data of Akaogi et al. [1989] and Jacobs and de Jong [2005] for the $\Delta G_{r}$ value. We investigated the transformation in a cold slab with a vertical subduction rate of $12 \mathrm{~cm} / \mathrm{yr}$ and a thermal gradient of $0.6 \mathrm{~K} / \mathrm{km}$, as representative of the West Pacific subduction zones. The temperature of the lithospheric mantle at $300 \mathrm{~km}$ was set to $800 \mathrm{~K}$, based on thermal model of Tetzlaff and Schmeling [2009]. The grain size in subducting plate is unconstrained and may lie in the range $0.01-10 \mathrm{~mm}$ [Riedel and Karato, 1997], a mean value of $5 \mathrm{~mm}$ was assumed in the calculation. This model is likely to be oversimplified as it does not consider the effect of latent heat released upon both kinetics and the thermal structure of the slab. For a more realistic model, the reader is referred to the recent work of Tetzlaff and Schmeling [2009]. Though schematic, the model provides an estimate of the effect of iron and water content on the metastable persistence of olivine at depth.

[22] The result of this thermo-kinetic model is presented in Figure 8. It is consistent with previous studies in predicting the presence of a metastable olivine wedge. However, the depth of the tip of the metastable wedge reaches a maximum of $740 \mathrm{~km}$, which is almost $70 \mathrm{~km}$ above the maximal depth of $810 \mathrm{~km}$ estimated from the kinetic parameters of Kubo et al. [2004a] for $\mathrm{Mg}_{2} \mathrm{SiO}_{4}$. Although the water content even more drastically reduces the persistence of metastable olivine (see Figure 8, calculations for 500-5000 ppm $\mathrm{H}_{2} \mathrm{O}$ hydrous $\mathrm{Mg}_{2} \mathrm{SiO}_{4}$, Hosoya et al. [2005]), the influence of the iron content cannot be neglected. These new results do not preclude the viability of the transformational faulting hypothesis for the deep focus earthquakes. Indeed, considering the inhibition of growth by transformation stress would widen the metastable olivine wedge to greater depths, while the effect of latent heat release is to lower the $\alpha-\beta$ transition boundary and speed up reaction kinetics. Intracrystalline nucleation and/or grain size reduction would also strongly enhance transformation rate and reduce the extent of metastable olivine. However, the increase of reaction rate with the iron content evidenced in the present study implies that the development of a metastable olivine wedge to depths $>660 \mathrm{~km}$, corresponding to the deepest earthquakes, would 


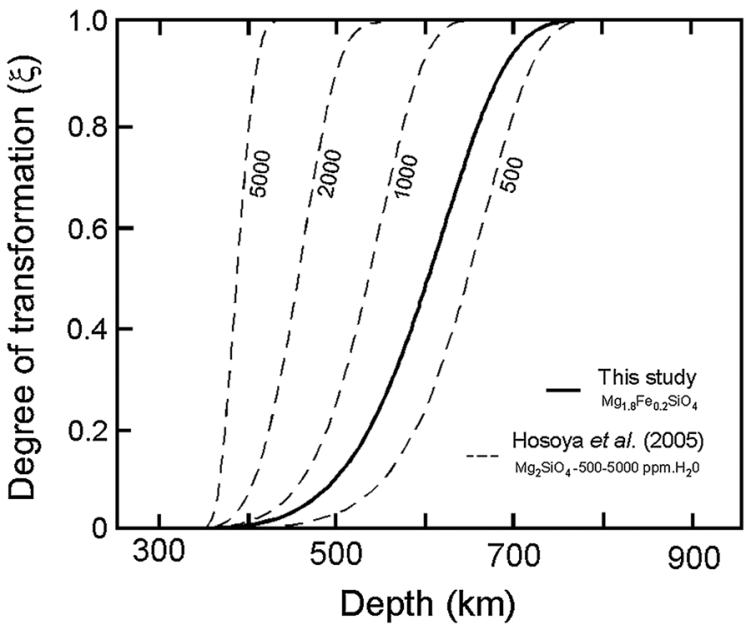

Figure 8. Fraction of olivine transformation as a function of depth for a cold slab with vertical subduction speed of $12 \mathrm{~cm} / \mathrm{yr}$ and a thermal gradient of $0.6 \mathrm{~K} / \mathrm{km}$. Thermokinetic calculations were performed using the present kinetic results for $\mathrm{Mg}_{1.8} \mathrm{Fe}_{0.2} \mathrm{SiO}_{4} \sim 500$ wt.ppm $\mathrm{H}_{2} \mathrm{O}$ (solid line) and the power-law dependence of growth rate on $\mathrm{OH}$ content with 500-5000 wt.ppm $\mathrm{H}_{2} \mathrm{O}$ in $\mathrm{Mg}_{2} \mathrm{SiO}_{4}$ from Hosoya et al. [2005] (dash lines). For comparison purpose, in both models, the activation volume was set to a similar value of $\mathrm{V}^{*}=0 \mathrm{~cm}^{3} / \mathrm{mol}$.

be restricted to even colder and/or dryer subduction zones than previously estimated.

[23] Acknowledgments. We acknowledge the European Synchrotron Radiation Facility for the allocation of synchrotron radiation beamtime. This work has been supported by the French Centre National de la Recherche Scientifique - Institut National des Sciences de l'Univers. Electron microscopy in Lyon is supported by the Centre Lyonnais de Microscopie.

\section{References}

Akaogi, M., E. Ito, and A. Navrotsky (1989), Olivine-modified spinel spinel transitions in the system $\mathrm{Mg}_{2} \mathrm{SiO}_{4}-\mathrm{Fe}_{2} \mathrm{SiO}_{4}$ : calorimetric measurements, thermochemical calculations, and geophysical application, J. Geophys. Res., 94(B11), 15671-15685.

Akimoto, S., and H. Fujisawa (1968), Olivine-spinel solid solution equilibria in the system $\mathrm{Mg}_{2} \mathrm{SiO}_{4}-\mathrm{Fe}_{2} \mathrm{SiO}_{4}, J$. Geophys. Res., 73(4), 1467-1479.

Bina C. R., S. Stein, F. C. Marton, and E. M. van Ark (2001), Implications of slab mineralogy for subduction dynamics, Phys. Earth Planet. Int., 127 (1-4), 51-66.

Bolfan-Casanova, N., H. Keppler, and D. C. Rubie (2000), Water partitioning between nominally anhydrous minerals in the $\mathrm{MgO}-\mathrm{SiO}_{2}-\mathrm{H}_{2} \mathrm{O}$ system up to $24 \mathrm{GPa}$ : Implications for the distribution of water in the Earth's mantle, Earth Planet Sci. Lett., 182, 209-221.

Brearley, A. J., D. C. Rubie and E. Ito (1992), Mechanisms of the transformations between the $\alpha, \beta$ and $\gamma$ polymorphs of $\mathrm{Mg}_{2} \mathrm{SiO}_{4}$ at $15 \mathrm{GPa}$, Phys. Chem. Miner., 18, 343-358.

Burnley, P. C., W. A. Bassett, and T. C. Wu (1995), Diamond anvil cell study of the transformation mechanism from the olivine to spinel phase in $\mathrm{Co}_{2} \mathrm{SiO}_{4}, \mathrm{Ni}_{2} \mathrm{SiO}_{4}$, and $\mathrm{Mg}_{2} \mathrm{SiO}_{4}$, J. Geophys. Res., 100, 17715-17723.

Burnley, P. C. (1995), The fate of olivine in subducting slabs: A reconnaissance study, Am. Mineral., 80, 1293-1301.

Cahn, J. W. (1956), The kinetics of grain boundary nucleated reactions, Acta Metall., 4, 449-459.

Chakraborty, S., R. Knoche, H. Schulze, D. C. Rubie, D. Dobson, N. L. Ross, and R. J. Angel (1999), Enhancement of cation diffusion rates across the 410-kilometer discontinuity in Earth's mantle, Science, 283, 362-365.

Chen, J. D., D. J. Weidner, J. B. Parise, M. T. Vaughan, and P. Raterron (2001), Observation of cationic reordering during olivine-spinel transition in fayalite by in situ synchrotron X-ray diffraction at high pressure and temperature, Physical Rev. Lett., 86, 4072-4075.
Chen, W. R., and M. R. Brudzinski (2001), Evidence for a large-scale remnant of subducted lithosphere beneath Fidji, Science, 292, 2475-2479.

Deon, F., M. Koch-Müller, D. Rhede, M. Gottschalk, R. Wirth, and S.M. Thomas (2010), Location and quantification of hydroxyl in wadsleyite: New insights, Am. Mineral., 95, 312-322.

Diedrich, T., T. G. Sharp, K. Leinenweber and J. R. Holloway (2009), The effect of small amounts of $\mathrm{H}_{2} \mathrm{O}$ on olivine to ringwoodite transformation growth rates and implications for subduction of metastable olivine, Chem. Geol., 262, 87-89.

Furnish, M. D. and W. A. Basset (1983), Investigation of the mechanism of the olivine-spinel transition in fayalite by synchrotron radiation, J. Geophys. Res., 88, 10,333-10,341.

Green, H. W. and P. C. Burnley (1989), A new, self-organizing, mechanism for deep-focus earthquakes, Nature, 341, 733-737.

Guyot, F., G. D. Gwanmesia and R. C. Liebermann (1991), An olivine to beta phase transformation mechanism in $\mathrm{Mg}_{2} \mathrm{SiO}_{4}$, Geophys. Res. Lett., $18,89-92$.

Hammersley A. P., S. O. Svensson, M. Hanfland, A. N. Fitch and D. Häusermann (1996), Two-dimensional detector software: From real detector to idealised image or two-theta scan, High Pressure Res., 14, 235-248.

Hernlund, J., K. Leinenweber, D. Locke, and J. A. Tyburczy (2006), A numerical model for steady-state temperature distributions in solidmedium high-pressure cell assemblies, Am. Mineral., 91, 295-305.

Holzapfel, C., S. Chakraborty, D. C. Rubie, and D. J. Frost (2009), Fe Mg interdiffusion in wadsleyite: The role of pressure, temperature and composition and the magnitude of jump in diffusion rates at the $410 \mathrm{~km}$ discontinuity, Phys. Earth Planet. Int., 172, 28-33, 10.1016/j.pepi.2008.09.005.

Hosoya, T., T. Kubo, E. Ohtani, A. Sano, and K. Funakoshi (2005), Water controls the fields of metastable olivine in cold subducting slabs, Geophys. Res. Lett., 32, L17305, doi:/10.1029/2005GL023398.

Jacobs, M. H. G., and B. H. W. S. de Jong (2005), An investigation into thermodynamic consistency of data for the olivine, wadsleyite and ringwoodite form of $(\mathrm{Mg}, \mathrm{Fe})_{2} \mathrm{SiO}_{4}$, Geochim. Cosmochim. Acta, 69, 17, 4361-4375.

Kaneshima, S., T. Okamoto, and H. Takenaka (2007), Evidence for a metastable olivine wedge inside the subducted Mariana slab, Earth Planet. Sci. Lett., 258, 219-227.

Karato, S., M. R. Riedel, and D. A. Yuen (2001), Rheological structure and deformation of subducted slabs in the mantle transition zone: Implication for mantle circulation and deep earthquakes, Phys. Earth Planet. Int., 127, 83-108, doi: 10.1016/S0031-9201(01)00223-0.

Katsura, T., H. Yamada, O. Nishikawa, M. Song, A. Kubo, T. Shinmei, S. Yokoshi, Y. Aizawa, T. Yoshino, M. J. Walter, and E. Ito (2004), Olivine-wadsleyite transition in the system $(\mathrm{Mg}, \mathrm{Fe})_{2} \mathrm{SiO}_{4}, J$. Geophys. Res., 109, B02209, doi:10.1029/2003JB002438.

Kawakatsu, H., and S. Yoshioka (2011), Metastable olivine wedge and deep dry cold slab beneath southwest Japan, Earth Planet. Sci. Lett., 303, doi:10.1016/j.epsl.2011.01.008.

Kerschhofer, L., T. G. Sharp and D. C. Rubie (1996), Intracrystalline transformation of olivine to wadsleyite and ringwoodite under subduction zone conditions, Science, 274, 79-81.

Kerschhofer, L., D. C. Rubie, T. G. Sharp, J. D. C. McConnell, and C. Dupas-Bruzek (2000), Kinetics of intracrystalline olivine-ringwoodite transformation, Phys. Earth Planet. Int., 121, 59-76.

Kirby, S. H. (1987), Localized polymorphic phase transformations in high pressure faults and its implications to the physical mechanism of deep earthquakes, J. Geophys. Res., 92, 13,789-13,800.

Kohlstedt, D. L., H. Keppler, and D. C. Rubie (1996), Solubility of water in the $\mathrm{a}, \mathrm{b}$ and $\mathrm{g}$ phases of $(\mathrm{Mg}, \mathrm{Fe})_{2} \mathrm{SiO}_{4}$. Contrib. Mineral. Petrol., 123, 345-357.

Kohn, S. C., R. A. Brooker, D. J. Frost, A. E. Slesinger, and B. J. Wood (2002), Ordering of hydroxyl defects in hydrous wadsleyite $\left(\beta-\mathrm{Mg}_{2} \mathrm{SiO}_{4}\right)$, Am. Mineral., 87, 293-301.

Kubo, T., E. Ohtani, T. Kato, T. Shinmei, and K. Fujino (1998), Experimental investigation of the $\alpha-\beta$ transformation of San Carlos olivine single crystal, Phys. Chem. Miner., 26, 1-6.

Kubo, T., E. Ohtani, and K. Funakoshi (2004a), Nucleation and growth kinetics of the $\alpha-\beta$ transformation in $\mathrm{Mg}_{2} \mathrm{SiO}_{4}$ determined by in situ synchrotron powder X-ray diffraction, Am. Mineral., 89, 285-293.

Kubo, T., A. Shimojuko, and E. Ohtani (2004b), Fe-Mg interdiffusion rates in wadsleyite and the diffusivity jump at the $410 \mathrm{~km}$ discontinuity, Phys. Chem. Miner., 31, 456-464.

Lacam, A., Madon, M. and J. P. Poirier (1980), Olivine glass and spinel formed in a laser heated, diamond-anvil high pressure cell, Nature, 289 , $155-157$.

Larson, A. C. and R. B. von Dreele (1994), General structure analysis system, Los Alamos Manual Report 86, 748.

Lauterjung, J. and G. Will (1986), The kinetics of the olivine-spinel transformation in $\mathrm{Mg}_{2} \mathrm{GeO}_{4}$ under high pressure and temperature, Physica, 139-140B, 343-346, doi:10.1016/0378-4363(86)90594-2. 


\section{PERRILLAT ET AL.: KINETICS OF $\alpha-\beta$ TRANSITION IN OLIVINE}

Libowitzky, E. and G. R. Rossman (1997), An IR absorption calibration for water in minerals, Am. Mineral., 82, 1111-1115.

Liu, M., L. D. Kershhofer, J. L. Mosenfelder, and D. C. Rubie (1998), The effect of strain energy on the growth rates during the olivine-spinel transformation and implication for olivine metastability in subducting slabs, J. Geophys. Res., 103, 23,897-23,909.

Madon, M., F. Guyot, J. Peyronneau and J. P. Poirier (1989), Electron microscopy of high-pressure phases synthesized from natural olivine in diamond anvil cell, Phys. Chem. Miner., 16, 320-330.

Madon, M. and J. P. Poirier (1983), Transmission electron microscopy of $\alpha$, $\beta$, and $\gamma(\mathrm{Mg}, \mathrm{Fe})_{2} \mathrm{SiO}_{4}$ in shocked meteorites: Planar defects and polymorphic transitions, Phys. Earth Planet. Int., 33, 31-44.

Martinez-Garcia, D., Y. Le Godec, M. Mezouar, G. Syfosse, J. P. Itié, and J. M. Besson (2000), Equations of state of $\mathrm{MgO}$ at high pressure and temperature, High Press. Res., 18 (1-6), 339-344.

Mezouar, M., P. Faure, W. A. Crichton, N. Rambert, B. Sitaud, S. Bauchau, and G. Blattmann (2002), Multichannel collimator for structural investigation of liquids and amorphous materials at high pressure and high temperature, J. Synchrotron Rad., 6, 1115-1119.

Mezouar, M., et al. (2005), Development of a new state-of-the-art beamline optimized for monochromatic single-crystal and powder Xray diffraction under extreme conditions at the ESRF, J. Synchrotron Rad., 12, 659-664.

Morard, G., et al. (2007), Optimization of Paris-Edinburgh press cell assemblies for in situ monochromatic X-ray diffraction and X-ray absorption, High Pressure Res., 27, 223-233.

Mosenfelder J. L., F. C. Marton, C. R. Ross, L. Kerschhofer, and D. C. Rubie (2001), Experimental constraints on the depth of olivine metastability in subducting lithosphere, Phys. Earth Planet. Int., 127, 165-180.

Perrillat, J. P. (2008), Kinetics of high-pressure mineral phase transformations using in situ time-resolved X-ray diffraction in the Paris-Edinburgh cell: A practical guide for data acquisition and treatment, Mineral. Mag., 72(2), 683-695

Poirier, J. P. (1981), On the kinetics of olivine-spinel transition, Phys. Earth Planet. Int., 26, 179-187.
Price, G. D., A. Putnis, and D. G. W. Smith (1982), A spinel to $\beta$-phase transformation mechanism in $(\mathrm{Mg}, \mathrm{Fe})_{2} \mathrm{SiO}_{4}$, Nature, 296, 729-731.

Raterron, P., J. Chen and D. J. Weidner (2002), A process for low-temperature olivine-spinel transition under quasi-hydrostatic stress, Geophys. Res. Lett., 29, 10.1029/2002GL015003.

Riedel, M. R., and S. Karato (1997), Grain-size evolution in subducted oceanic lithosphere associated with the olivine-spinel transformation and its effect on rheology, Earth Planet Sci. Lett., 148, 27-43.

Ringwood, A. E. and A. Major (1966), Some high pressure transformations in olivines and pyroxenes, J. Geophys. Res., 71(18), 4448.

Ringwood, A. E. (1975), Composition and Petrology of the Earth's Mantle, McGraw-Hill, New York, pp. 618.

Rubie, D. C. and C. R. Ross (1994), Kinetics of the olivine-spinel transformation in subducting lithosphere: Experimental constraints and implications for deep slab processes, Phys. Earth Planet. Int., 86, 223-241.

Shim, S. H., T. S. Duffy, and T. Kenichi (2002), Equation of state of gold and its application to the phase boundaries near the $660 \mathrm{~km}$ depth in Earth's mantle, Earth Planet. Sci. Lett., 203, 729-739.

Singh, A. K., and G. C. Kennedy (1974), Uniaxial stress component in tungsten carbide anvil high-pressure X-ray cameras, J. Appl. Phys., 45, 4686, doi:10.1063/1.1663119.

Stein, S., and C. A. Stein (1996), Thermo-chemical evolution of oceanic lithosphere: Implications for the subduction process and deep earthquakes, in Debout, G. E., Scholl, D. W., Kirby, S. H., Platt, J. P. (Eds), Subduction: Top to Bottom, AGU Monograph, 96, Washington DC, 1-17.

Sung C. M. and R. G. Burns (1976), Kinetics of the olivine-spinel transition: Implications to deep-focus earthquake genesis, Earth Planet. Sci. Lett., 32, 165-170.

Tetzlaff, M., and H. Schmeling (2009), Time-dependent interaction between subduction dynamics and phase transition kinetics, Geophys. J. Int., 178, 826-844.

Turnbull, D. (1956), Phase changes, Solid State Phys., 3, 225-306.

Yamazaki, D., T. Inoue, M. Okamoto, and T. Irifune (2005), Grain growth kinetics of ringwoodite and its implication for rheology of the subducting slab, Earth Planet. Sci. Lett., 236 (3-4), 871-881. 